\title{
Analisis Perkembangan Kasus COVID-19 Berkaitan dengan Kebijakan Pemerintah di Pulau Jawa
}

\author{
Charvia Ismi Zahrani ${ }^{1}$, Setia Pramana ${ }^{1,2}$ \\ 1 Politeknik Statistika STIS \\ 2 Badan Pusat Statistik Indonesia \\ Jalan Otista No.64C RT.1/RW.4, Bidara Cina, Jatinegara, Jakarta Timur. \\ Korespondensi E-mail: setia.pramana@stis.ac.id
}

Submitted: 19 November 2020, Revised: 13 Juni 2021, Accepted: 16 Juni 2021

\begin{abstract}
COVID-19 is a serious problem that faced by almost all countries in the world. Since announced as a pandemic by WHO on March, the number of positive COVID-19 cases in Indonesia has reached 287,008 patients until the end of September 2020. COVID-19 cases dispersion depends on the local government policies and the awareness of the public to obey. About 60 percent of positive cases and 65 percent of death cases were in Java. Therefore, the aim of this study is to analyze the growth of the COVID-19 case in Java from March to September 2020 in relation to the local government policies. The results showed that six provinces in Java had the same pattern. The large-scale social restriction (PSBB), which was implemented since April 10 2020, seen to be able to contain the dispersion of cases because from April to June the positive cases did not increase significantly. A very high increase occurred in August and September, this was probably due to the easing of the PSBB become new-normal where various public places and facilities have been reopened. Meanwhile, death cases, the number is very bigh in mid-April and June and late July to September 2020. For cured cases, there was a significant increase in late August to September 2020. The importance of information about the growth of the COVID19 cases can belp government to formulate strategies and policies to prevent the dispersion of COVID-19.
\end{abstract}

Keyword: COVID-19, pandemic, Java, cases growth

\begin{abstract}
Abstrak
COVID-19 merupakan suatu masalah serius yang sedang dihadapi oleh hampir seluruh negara. Sejak diumumkan sebagai pandemi oleh WHO pada Maret lalu, jumlah kasus positif COVID-19 di Indonesia mencapai 287.008 pasien hingga akhir September. Penyebaran kasus COVID-19 sangat bergantung pada kebijakan yang ditetapkan oleh pemerintah serta kesadaran masyarakat untuk mematuhinya. Sebesar 60 persen kasus positif dan 65 persen kasus meninggal berada di Pulau Jawa. Oleh karena itu, tujuan penelitian ini adalah menganalisis perkembangan kasus COVID-19 di Pulau Jawa sejak Bulan Maret-September 2020 dikaitkan dengan kebijakan pemerintah setempat. Hasil penelitian menunjukkan bahwa keenam provinsi memiliki pola yang sama. Pembatasan Sosial Berskala Besar (PSBB) yang dilakukan sejak 10 April 2020 terlihat dapat menahan penyebaran kasus karena pada bulan April-Juni 2020 kasus positif tidak mengalami kenaikan yang signifikan. Kenaikan yang sangat tinggi terjadi pada bulan Agustus dan September 2020, hal ini mungkin disebabkan oleh dilonggarkannya kebijakan PSBB menjadi PSBB Transisi dimana berbagai tempat dan fasilitas umum telah dibuka kembali. Sementara untuk kasus meninggal, angka tertinggi terjadi pada pertengahan April dan Juni serta akhir Juli hingga September 2020. Untuk kasus sembuh, terjadi peningkatan yang signifikan pada akhir Agustus hingga September 2020. Pentingnya informasi tentang perkembangan kasus COVID-19 ini dapat membantu pemerintah daerah untuk membuat strategi dan kebijakan untuk mencegah penyebaran rantai virus COVID-19.
\end{abstract}

Kata Kunci: COVID-19, pandemi, Jawa, perkembangan kasus

\section{Pendahuluan}

Pada awal tahun 2020, dunia dikejutkan dengan adanya wabah COVID-19 yang menyerang hampir seluruh negara. COVID-19 adalah penyakit menular yang disebabkan oleh virus korona. Virus baru ini pertama kali terdeteksi di sebuah laboratorium di Wuhan, Cina yang menyebar melalui tetesan air liur atau cairan dari hidung. Kebanyakan orang yang terinfeksi virus COVID-19 akan mengalami penyakit pernapasan ringan hingga sedang dan akan sembuh tanpa memerlukan perawatan khusus (1). Kondisi ini menyebabkan sebagian orang menyepelekan dan menganggap gejalanya hanya sebatas penyakit influenza biasa padahal menurut analisis kedokteran, virus ini berbahaya dan dapat menyebabkan kematian. 
Penularan virus COVID-19 cukup signifikan karena penyebarannya terjadi secara global, termasuk di Indonesia. Kasus pertama terjadi pada bulan Februari dan hingga tanggal 30 September 2020, jumlah kasus COVID-19 telah mencapai 287.000 pasien. Dalam 11 hari setelah kasus pertama diumumkan, jumlah kasus positif mencapai 69 orang, 4 diantaranya meninggal dan 5 kasus sembuh. Pesatnya perkembangan kasus ini mendesak pemerintah untuk mengeluarkan berbagai kebijakan yang dianggap dapat menekan penyebarannya. Pemerintah pusat telah mengeluarkan status darurat bencana terhitung mulai tanggal 29 Februari 2020 hingga 29 Mei 2020 terkait virus ini dengan jumlah waktu 91 hari (2). Beberapa kebijakan yang diterapkan adalah membatasi aktifitas keluar rumah, merumahkan kegiatan bersekolah, hingga merumahkan kegiatan beribadah. Namun pada kenyataannya, terdapat disharmonisasi antara kebijakan yang dibuat oleh Pemerintah Pusat dengan kebijakan Pemerintah Daerah di awal masa pandemi. Perbedaan tersebut dimulai ketika beberapa daerah menerapkan kebijakan lockdown sementara pemerintah pusat menetapkan kebijakan Pembatasan Sosial Berskala Besar (PSBB). Meski terdapat perbedaan, berbagai kebijakan tersebut telah membuat pola mobilitas masyarakat di rumah dan berbagai tempat publik berbeda (3). Hal ini berpengaruh terhadap tingkat penyebaran COVID-19.

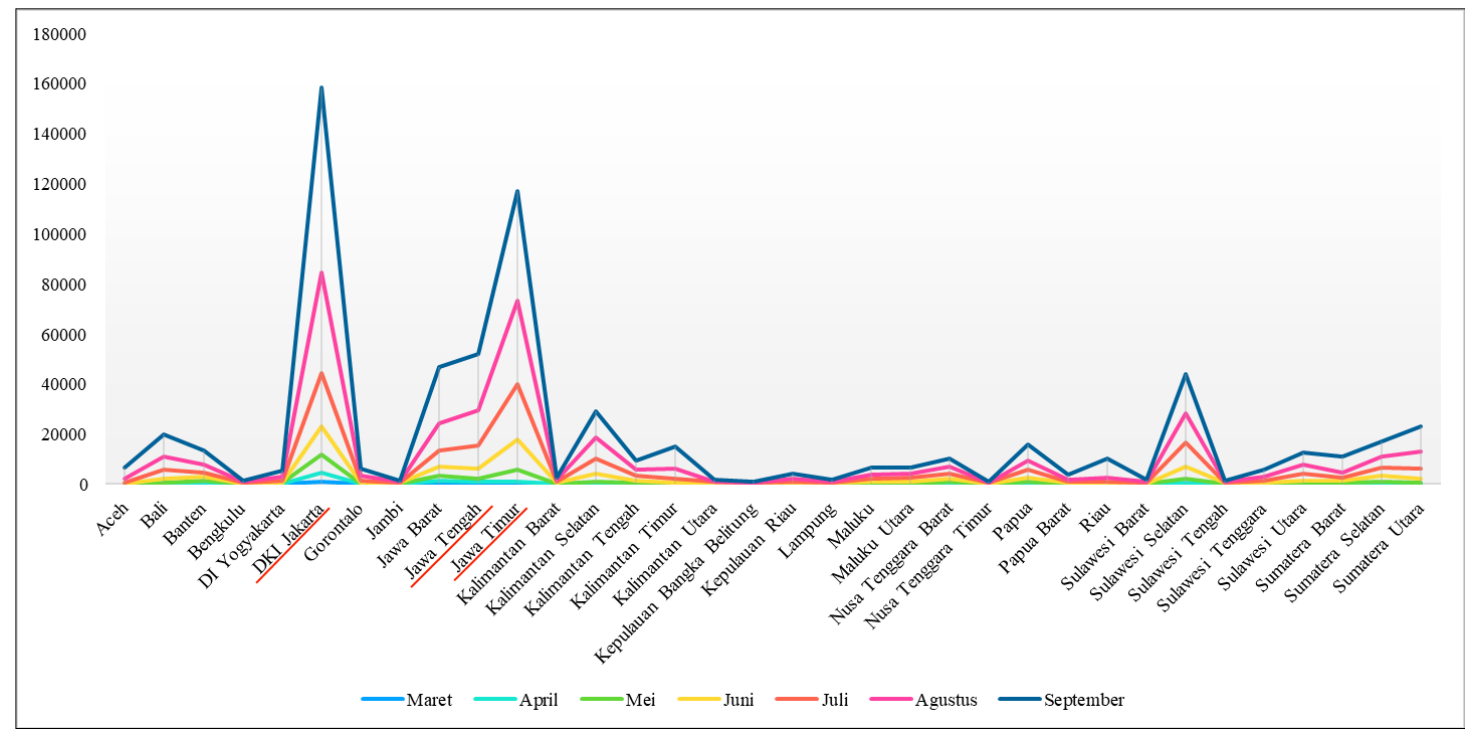

Gambar 1.

Jumlah Kasus Positif COVID-19 di Indonesia Menurut Provinsi Periode Maret-September 2020 Sumber: covid19.go.id (diolah)

Di Indonesia, lebih dari 60 persen kasus positif dan 65 persen kasus meninggal berada di Pulau Jawa (4). Hal ini menunjukkan bahwa lebih dari separuh kasus positif serta kasus meninggal yang ada di Indonesia terdapat di Pulau Jawa. Gambar 1 memperlihatkan bahwa provinsi dengan jumlah kasus positif terbanyak adalah DKI Jakarta, Jawa Timur, dan Jawa Tengah. Ketiga provinsi ini berada di Pulau Jawa. Hal ini memperihatinkan mengingat DKI Jakarta merupakan ibu kota yang juga menjadi pusat perekonomian Indonesia. Hal ini juga mungkin berkaitan dengan padatnya penduduk Pulau Jawa sehingga menyebabkan penyebaran kasus berlangsung lebih cepat. Pemerintah Daerah yang berada di Pulau Jawa harus memberikan perhatian khusus guna menekan kasus penyebaran COVID-19 mengingat dampak negatif yang ditimbulkan dapat menyebabkan maslaah serius termasuk kematian. Hal ini menjadi tantangan tersendiri untuk pemerintah setempat karena perkembangan kasus sangat bergantung pada kebijakan yang diterapkan. Oleh karena itu, tujuan dari penelitian ini adalah melakukan analisis terhadap perkembangan kasus COVID-19 di Pulau Jawa sejak bulan Maret hingga September 2020 dikaitkan dengan kebijakan yang telah ditetapkan oleh pemerintah setempat. 


\section{Metode Penelitian}

\section{Kajian Teori}

Kementrian Kesehatan RI (2020) menjelaskan bahwa COVID-19 merupakan suatu penyakit yang disebabkan oleh virus SARS-COV2 yang termasuk dalam keluarga coronavirus yang sama dengan penyebab SARS pada tahun 2003. Seperti penyakit pernapasan lainnya, COVID-19 dapat menyebabkan gejala ringan termasuk pilek, sakit tenggorokan, batuk, dan demam. Walaupun angka kematian penyakit ini masih terbilang rendah, yaitu sekitar 3 persen, tetapi bagi balita, lansia, dan orang-orang dengan riwayat penyakit lain sebelumnya, penyakit ini lebih berisiko untuk menyebabkan kematian. Kejadian COVID-19 terjadi kebanyakan pada pasien pria berumur 34 hingga 59 tahun. Virus ini cenderung menginfeksi orang dengan komorbid kronis seperti penyakit jantung dan diabetes. Kasus parah biasanya terjadi pada pasien berumur lebih dari 60 tahun dengan berbagai komorbid (5). Untuk kasus di Indonesia, selama 2 Maret hingga 2 Agustus 2020, terdapat 67.79 persen kasus yang sembuh, dan 4.83 persen meninggal. Kebanyakan dari pasien adalah laki-laki (50,52 persen) dan orang dewasa berumur 31-45 tahun (29.73 persen) (6). Meski episentrum adalah di Jabodetabek, tetapi semua provinsi telah terdapat kasus positif.

Melihat perkembangan hingga saat ini, lebih dari 50\% kasus terkonfirmasi telah dinyatakan membaik, dan angka kesembuhan akan terus meningkat (7). WHO dan Kementerian Kesehatan RI menyatakan bahwa penularan virus ini terjadi melalui tetesan kecil atau disebut droplet yang dikeluarkan saat seseorang batuk atau bersin. Droplet tersebut kemudian jatuh pada benda yang ada di sekitarnya kemudian saat orang lain menyentuh benda yang terkontaminasi droplet tersebut, dan menyentuh area mata, hidung, atau mulut maka orang itu dapat terinfeksi virus COVID-19 (8). Inilah sebabnya mengapa sangat penting untuk menjaga jarak dari orang lain saat masa pandemi ini.

Awalnya pemerintah tidak ingin terlalu banyak memberikan informasi kepada masyarakat terkait virus corona yang masuk ke Indonesia untuk menghindari kepanikan masyarakat dan menghindari isuisu yang tidak jelas kebenarannya (9). Namun jumlah kasus terkonfirmasi terus mengalami peningkatan sehingga pemerintah perlu melakukan berbagai upaya guna meminimalisir penyebaran virus COVID-19. Pada bulan Maret, Presiden melakukan siaran pers yang menyuluhkan masyarakat untuk bekerja dari rumah, belajar dari rumah, dan beribadah di rumah. Sejak saat itu, pemerintah bersama seluruh lapisan masyarakat melakukan akitivitas dengan pembatasan social (social distancing) demi mencegah penularan virus COVID-19. Sejak 15 Maret 2020, Presiden menyerahkan penentuan status kedaruratan daerah kepada kepala daerah masing-masing. Kebijakan yang dibuat oleh pemerintah daerah terlebih dahulu diperiksa secara ketat dengan mempertimbangkan konsekuensinya sacara matang, baik dari segi ekonomi maupun segi sosial.

Presiden Joko Widodo telah menetapkan peraturan tentang Pembatasan Sosial Berskala Besar (PSBB) melalui Peraturan Pemerintah (PP) Nomor 21 Tahun 2020 yang mulai berlaku sejak 1 April 2020. Pemerintah daerah yang ingin memberlakukan PSBB di daerahnya harus mendapat persetujuan terlebih dahulu dari pemerintah pusat. Mekanisme dan indikator penerapan PSBB di tingkat daerah diatur secara rinci dalam Peraturan Menteri Kesehatan Nomor 9/2020 (10). Provinsi pertama yang mengajukan PSBB adalah DKI Jakarta, dimana wilayah ini merupakan wilayah dengan kasus korona paling tinggi. Pemberlakuan PSBB DKI Jakarta belangsung selama 2 minggu pada tanggal 10-24 April 2020. Pengajuan PSBB DKI Jakarta ini kemudian diikuti oleh wilayah Jawa Barat, yaitu Bogor, Depok, dan Bekasi. Pengajuan ini dilakukan oleh pemeritah setempat pada 11 April 2020. Provinsi Jawa Timur dan Jawa Tengah juga menerapkan PSBB namun hanya di beberapa kabupaten yang merupakan zona merah. Sementara provinsi lain di Pulau Jawa yaitu Banten dan DI Yogyakarta belum menerapkan kebijakan PSBB hingga Bulan September.

Adanya pembatasan aktivitas masyarakat membuat pertumbuhan ekonomi Indonesia cenderung stagnan. Demi mencegah situasi ekonomi Indonesia semakin tidak kondusif, pemerintah mulai melihat kemungkinan untuk melakukan relaksasi pembatasan sosial dengan mengadakan tatanan normal baru atau disebut The new normal (10). Kebijakan The new normal didasarkan kepada pertimbangan bahwa virus COVID-19 tidak akan hilang dalam waktu dekat sebagaimana hasil kajian yang dilakukan oleh WHO, sehingga tidak mungkin untuk menghentikan aktivitas ekonomi dan sosial yang dapat mengancam keberlanjutan pertumbuhan dan pembangunan suatu negara (11). 
Penerapan The new normal dilakukan dengan tetap menaati protokol kesehatan diantaranya selalu memakai masker, rajin mencuci tangan, dan menjaga jarak dengan orang lain. Kebijakan ini diharapkan menghasilkan sinergitas keberlanjutan aktivitas ekonomi dan sosial masyarakat dengan upaya penanggulangan COVID-19 di masing-masing daerah. Kebijakan yang dianjurkan dilakukan untuk pengetatan diam di rumah, menurunkan penyebaran penyakit dengan karantina wilayah dalam skala besar, meningkatkan pelayanan kesehatan, serta meningkatkan ketersediaan alat pelindung diri (APD) (12). Selain itu terdapat kesenjangan dan batasan dalam respon pemerintah dalam penanggulangan COVID-19 (13). Mereka memberikan lima rekomendasi untuk respon yang lebih cepat, efektif, dan komprehensif. Rekomendasi tersebut adalah:

1. Memperkuat respons kesehatan seperti yang disarankan oleh WHO

2. Proaktif dan memperkuat koordinasi selama krisis dan situasi darurat

3. Memperkuat ketahanan ekonomi

4. Memanfaatkan pengambilan keputusan yang multi-disiplin berbasis sains yang salah satunya didukung oleh data besar

5. Mempromosikan pendekatan inklusif dan berbasis masyarakat untuk ketahanan dan kesiapan kesehatan masyarakat

Survei Perilaku Perilaku Masyarakat di Masa Pandemi Covid-19 Badan Pusat Statistik memperlihatkan bahwa masyarakat sudah berangsur mengikuti anjuran pemerintah untuk melakukan perubahan perilaku dan memperhatikan protokol kesehatan seperti memakai masker, mencuci tangan dan menjauhi kerumunan (14).

\section{Sumber Data}

Data yang digunakan merupakan data sekunder time series yang berasal dari website covid19.go.id yang dibentuk oleh komite penanganan COVID-19 dan pemulihan ekonomi nasional (KPCPEN). Komite ini merupakan sebuah komite yang dibentuk oleh pemerintah dalam rangka pemulihan ekonomi dan penanggulangan penyakit koronavirus 2019 dan pandemi COVID-19 di Indonesia pada tanggal 20 Juli 2020 sesuai dengan Peraturan Presiden Nomor 82 Tahun 2020. Penelitian ini juga menggunakan data sekunder berupa Google Mobility Index. Indeks ini merupakan indeks yang menunjukkan persentase perubahan jumlah/lama kunjungan seseorang ke beberapa tempat dalam suatu hari dibandingkan dengan baseline days. Nilai baseline yang digunakan merupakan median dari data kunjungan pada periode 3 Januari - 6 Februari 2020. Unit analisis dalam penelitian ini adalah enam provinsi yang berada di Pulau Jawa yaitu Banten, Jawa Barat, DKI Jakarta, Jawa Tengah, DI Yogyakarta, dan Jawa Timur.

\section{Metode Analisis}

Metode analisis yang digunakan dalam penelitian ini adalah analisis deskriptif berupa penyajian grafik. Analisis deskriptif merupakan suatu teknik analisis yang memberikan informasi tentang data yang dimiliki dan tidak bermaksud menguji hipotesis. Analisis ini bertujuan untuk melihat gambaran umum dari perkembangan kasus COVID-19 di enam provinsi di Pulau Jawa berkaitan dengan kebijakan yang diterapkan oleh pemerintah setempat sejak bulan Maret hingga September 2020. Perkembangan kasus yang diteliti dibagi menjadi tiga bagian, yaitu jumlah pasien terkonfirmasi, jumlah pasien sembuh, dan jumlah pasien meninggal. Google Index Mobility di berbagai tempat juga ditampilkan untuk memperlihatkan bagaimana perubahan dari mobilitas masyarakat serta efektifitas pembatasan mobilitas masyarakat.

\section{Hasil dan Pembahasan}

\section{Gambaran Umum Perkembangan Kasus COVID-19 di Pulau Jawa}

Analisis deskriptif dilakukan kepada enam provinsi yang ada di Pulau Jawa yang kemudian dilakukan perbandingan dari masing-masing provinsinya. Berdasarkan pengolahan data, Gambar 2 menunjukkan bahwa kasus terkonfirmasi positif COVID-19 di Pulau Jawa terus mengalami peningkatan setiap bulannya. Dapat dilihat bahwa provinsi dengan kasus terbanyak adalah DKI Jakarta sementara yang terendah adalah DI Yogyakarta. Tingginya kasus yang terjadi di DKI Jakarta mungkin berkaitan dengan padatnya penduduk Kota Jakarta. Sebagai ibu kota yang merupakan pusat berbagai macam kegiatan baik dari segi pemerintahan maupun perekonomian, sulit untuk menghentikan berbagai aktivitas 
secara total sehingga tingkat penularan yang terjadi di Jakarta juga lebih tinggi dibandingkan provinsi lain. Selain itu, pemeriksaan atau testing seperti rapid dan swab test juga lebih mudah ditemukan di Jakarta, hal ini membuat kasus yang terkonfirmasi terus bertambah karena pemeriksaan terus dilakukan. Jika dilihat berdasarkan pola perkembangan setiap bulannya, ditemukan pola yang serupa pada semua provinsi, yaitu kenaikan drastis terjadi pada bulan September, hal ini mungkin berkaitan dengan kebijakan kebiasaan baru atau new normal yang diterapkan oleh pemerintah.

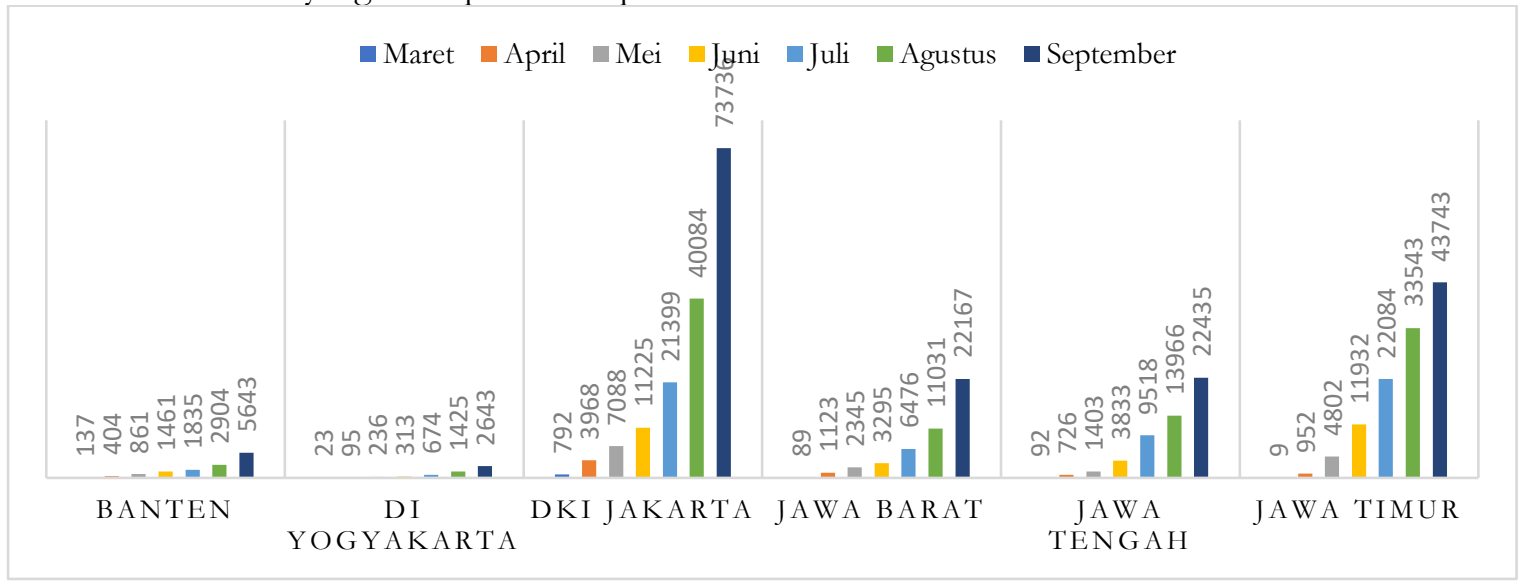

Gambar 2.

Jumlah Kasus Terkonfirmasi di Pulau Jawa pada Bulan Maret-September 2020

Sumber: covid19.go.id (diolah)

Meskipun kasus terkonfirmasi terbanyak terjadi di DKI Jakarta, hasil yang berbeda ditunjukkan oleh Gambar 3. Terlihat bahwa provinsi dengan kasus meninggal terbanyak adalah Jawa Timur. Temuan ini mengindikasikan bahwa tingkat kematian yang ada di Jawa Timur lebih tinggi dibandingkan DKI Jakarta. Hal ini mungkin terjadi karena fasilitas kesehatan seperti Rumah Sakit ataupun Puskesmas yang memadai lebih mudah ditemukan di Jakarta dibandingkan di Jawa Timur. Epidemiolog Universitas Airlangga, Windhu Purnomo, menyatakan bahwa tingginya angka kematian akibat COVID-19 di Jawa Timur disebabkan oleh beberapa faktor. Faktor pertama adalah tingginya jumlah pasien COVID-19 yang berasal dari kategori risiko tinggi; yakni pasien lansia, pasien balita, dan pasien yang memiliki penyakit bawaan lainnya atau kormobid. Faktor kedua adalah kapasitas ruang isolasi rumah sakit yang ada di Jawa Timur tidak sebanding dengan pertambahan pasien terkonfirmasi. Faktor lainnya yang juga menyebabkan kondisi ini adalah keterlambatan pasien datang ke rumah sakit. Selain itu, laboratorium COVID-19 di Jawa Timur belum merata melainkan hanya terkonsentrasi di Surabaya, sehingga banyak pasien yang berada di kabupaten baru terdeteksi terkena virus COVID-19 saat sudah mengalami sakit parah dan kemudian meninggal dunia (15).

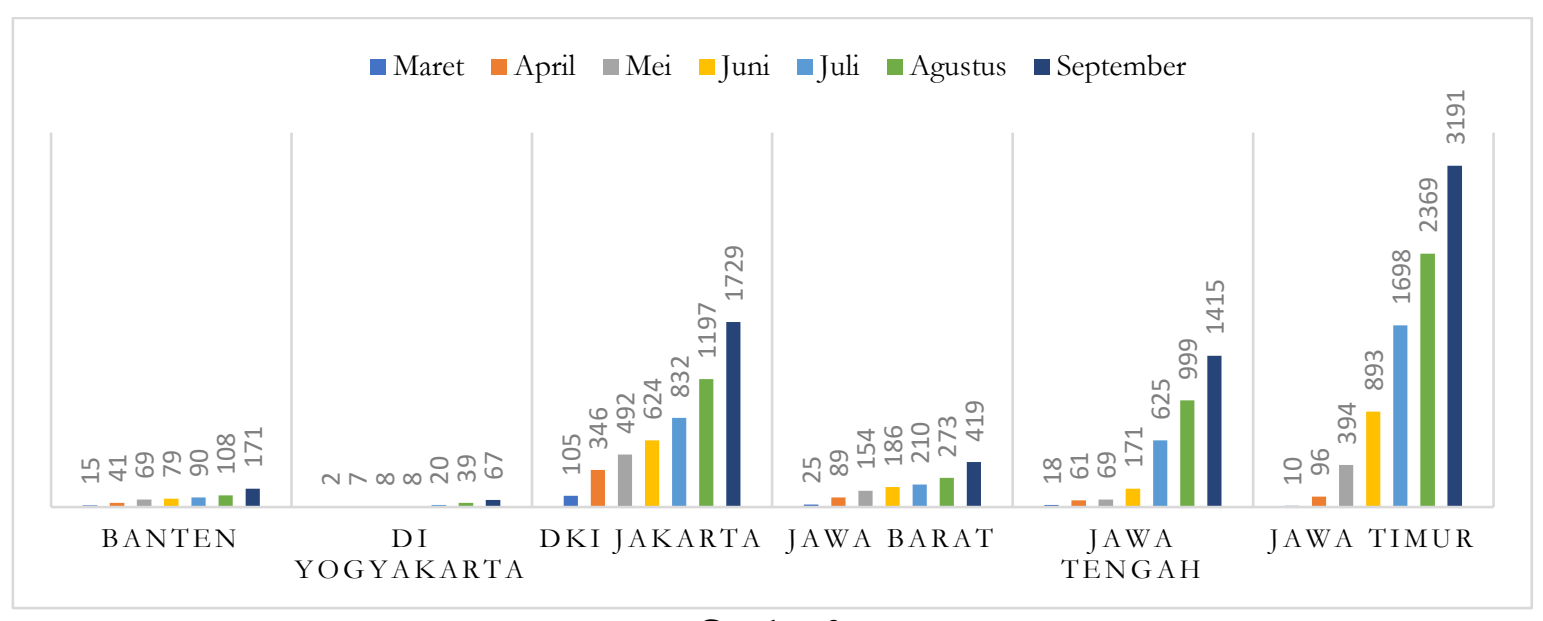

Gambar 3.

Jumlah Kasus Meninggal di Pulau Jawa pada Bulan Maret-September 2020

Sumber: covid19.go.id (diolah) 
Seperti kasus terkonfirmasi dan kasus meninggal, kasus pasien yang sembuh dari virus COVID19 terus mengalami peningkatkan setiap bulannya. Ini merupakan hal yang baik yang menandakan bahwa cara-cara yang dilakukan untuk menyembuhkan pasien yang terkena virus COVID-19 semakin hari semakin membaik. Jika dilihat antar provinsi seperti yang disajikan pada Gambar 4, daerah yang memiliki jumlah kasus sembuh terbanyak adalah DKI Jakarta sementara yang terendah adalah DI Yogyakarta. Hal ini sejalan dengan banyaknya kasus terkonfirmasi pada Gambar 2. Tingginya kasus sembuh di Jakarta disebabkan oleh banyaknya rumah sakit rujukan yang ada di Jakarta sehingga setiap pasien yang terkonfirmasi positif virus COVID-19 dapat langsung mendapat penanganan dan pengobatan. Sementara untuk DI Yogyakarta, kasus sembuh sangat sedikit dikarenakan pasien yang terindikasi positif juga paling sedikit dibandingjkan provinsi lainnya.

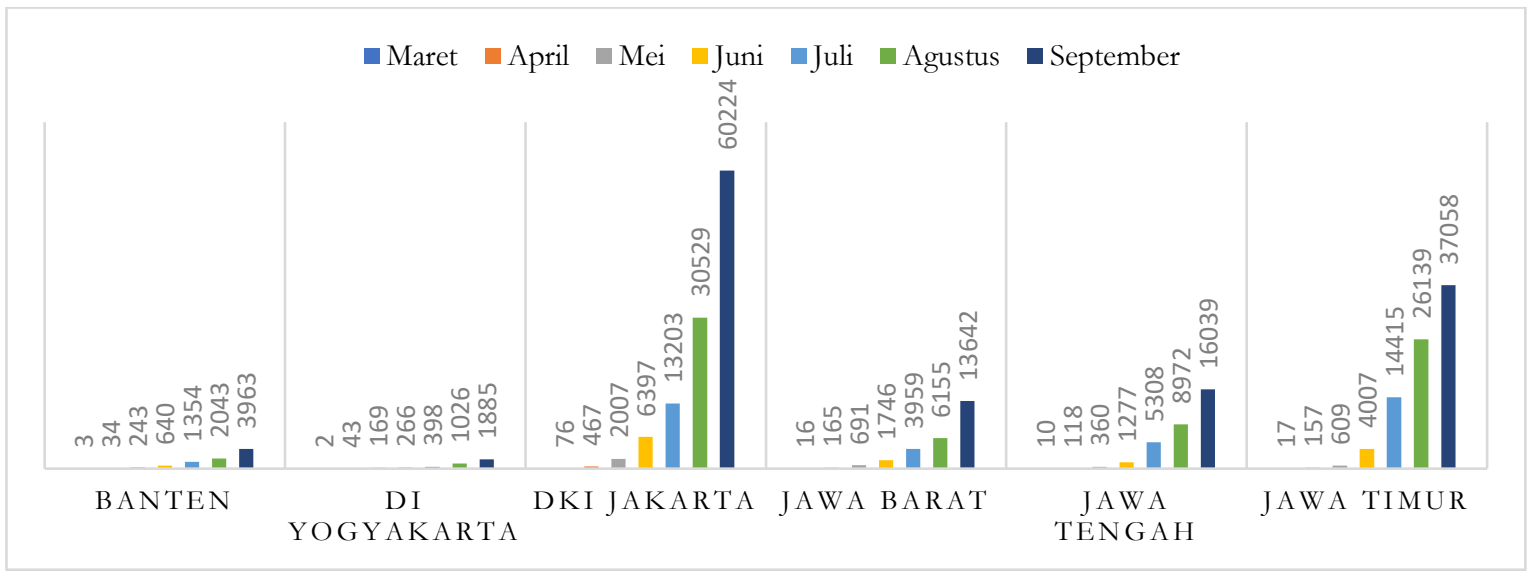

Gambar 4.

Jumlah Kasus Sembuh di Pulau Jawa pada Bulan Maret-September 2020

Sumber: covid19.go.id (diolah)

Analisis Mobilitas Masyarakat pada Era COVID-19 Berhubungan dengan Kebijakan Pemerintah di Pulau Jawa

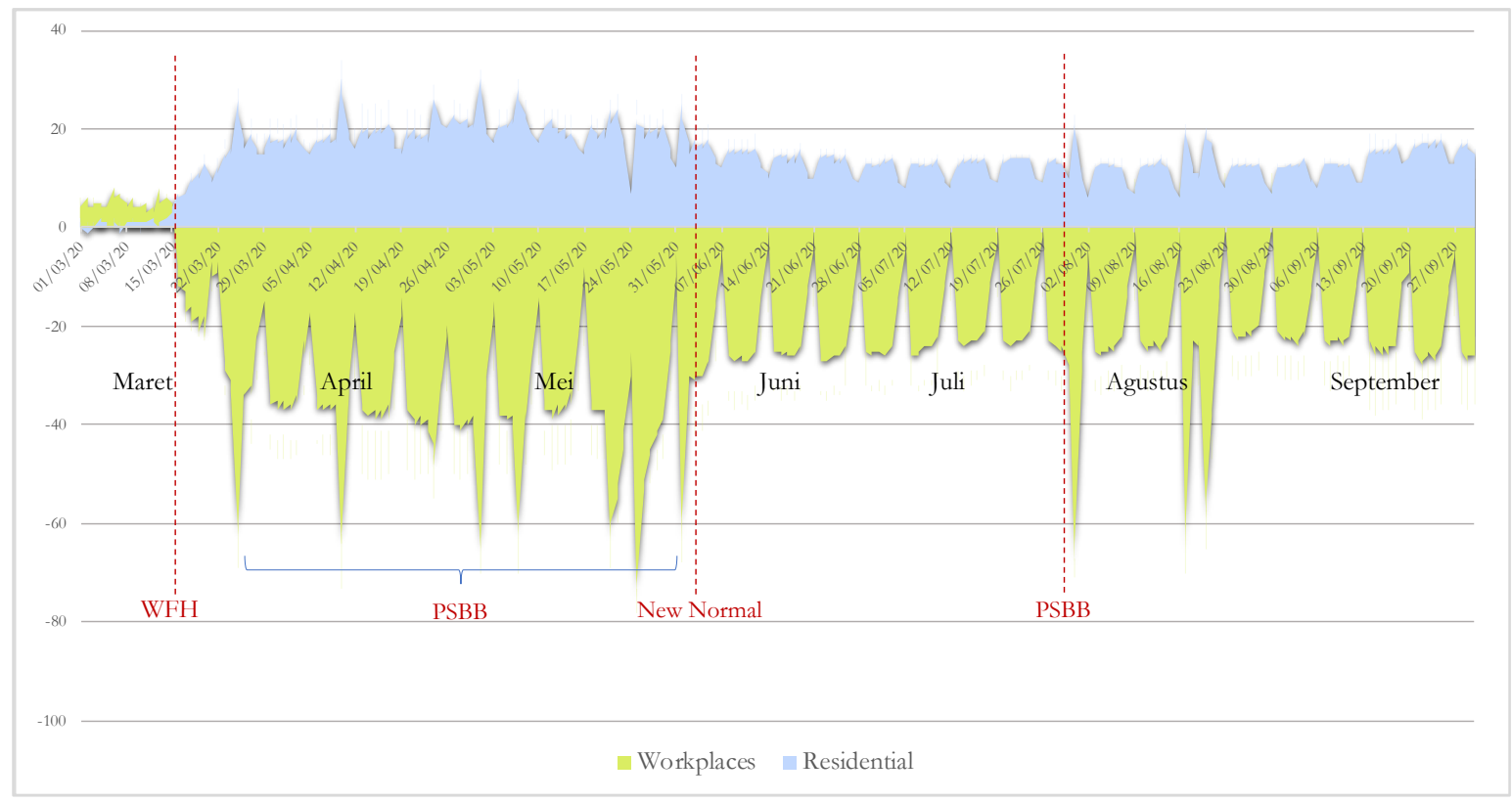

Gambar 5.

Mobilitas Masyarakat di Tempat Kerja dan Rumah pada Bulan Maret-September 2020

Sumber: Google Mobility Index (diolah) 
Berdasarkan hasil pengolahan data Google Mobilty Index seperti pada Gambar 5 terlihat bahwa penurunan drastis mobilitas di tempat kerja terjadi setelah tanggal 16 Maret, bertepatan dengan kebijakan Work From Home yang ditetapkan oleh pemerintah DKI Jakarta yang juga menyebabkan penurunan mobilitas ke daerah sekitar DKI Jakarta. Penurunan ini sejalan dengan peningkatan mobilitas masyarakat di rumah. Kemudian pemerintah menerapkan kebijakan Pembatasan Sosial Berskala Besar (PSBB) yang dimulai oleh DKI Jakarta yaitu awal April yang kemudian diikuti oleh Jawa Barat dan Jawa Timur pada akhir April. Penerapan PSBB ini berdampak pada menurunnya mobilitas di tempat kerja serta meningkatnya mobilitas di rumah sejak Bulan April hingga Mei.

Pada tanggal 5 April pemerintah mengeluarkan kebijakan New Normal sehingga sejak saat itu, masyarakat kembali bekerja di kantor dan beraktivitas di luar rumah. Terlihat pada gambar bahwa mobilitas masyarakat sejak saat itu kembali mendekati baseline days yang menandakan bahwa mobilitas juga mendekati keadaan normal sebelum PSBB meskipun perubahannya tidak terlalu drastis karena kegiatan masyarakat hanya kembali aktif sebesar 50\%. Kemudian peningkatan kasus terkonfirmasi yang kian meningkat pada awal Bulan Agustus membuat pemerintah kembali menerapkan kebijakan PSBB pada minggu pertama. Hal ini terlihat dengan menurunnya mobilitas ke kantor pada bulan Agustus. Sementara untuk mobilitas di rumah, hanya terjadi perubahan sedikit. Hal ini mungkin terjadi karena masyarakat sudah jera berada di rumah.

Tempat Perdagangan Retail \& Rekreasi

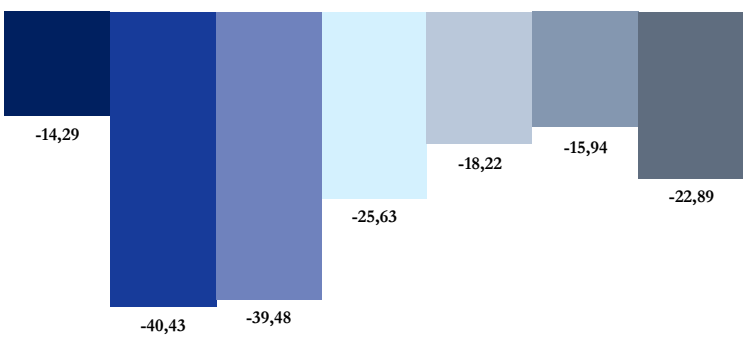

Taman

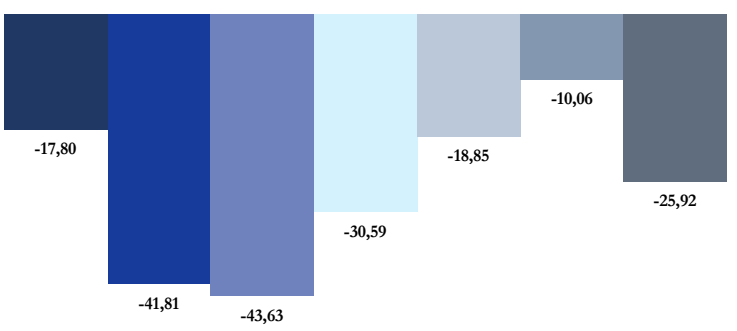

Maret
April
Mei

Juni $\square$ Juli

Tempat Belanja Kebutuhan Seharihari

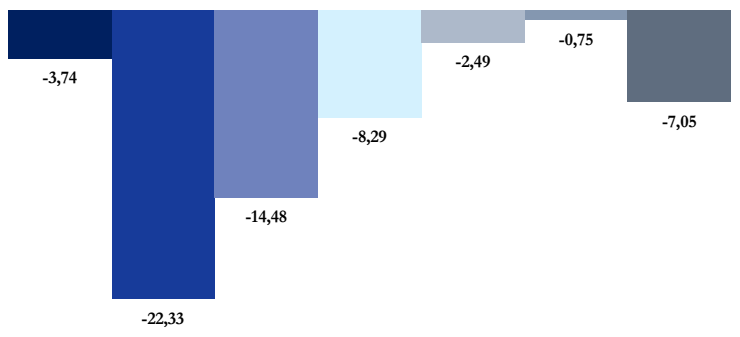

Stasiun \& Tempat Transit

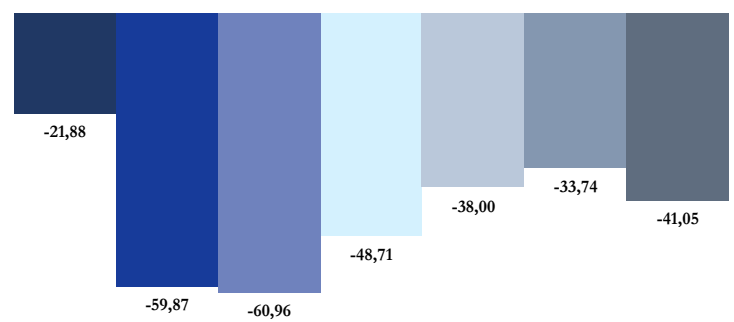

September

Gambar 6.

Mobilitas Masyarakat di Berbagai Tempat dan Fasilitas Umum pada Bulan Maret-September di Pulau Jawa

Sumber: Google Mobility Index (diolah)

Selain mobilitas di tempat kerja dan di rumah, perubahan mobilitas masyarakat juga mengalami penurunan drastis di beberapa tempat seperti temopat perdagangan, tempat berbelanja kebutuhan sehari-hari, taman, serta stasiun dan tempat transit. Penurunan paling signifikan terjadi pada Bulan April saat kebijakan PSBB dilaksanakan. Tempat yang mengalami penurunan paling besar adalah stasiun dan tempat transit yaitu sebesar 61 persen. Hal ini sangat wajar terjadi karena transportasi umum pada saat PSBB dilarang beroperasi. Sementara tempat yang mengalami penurunan paling kecil adalah tempat untuk berbelanja kebutuhan sehari-hari yakni hanya sebesar 22 persen. Hal ini disebabkan oleh tingginya ketergantungan masyarakat akan kebutuhan sehari-hari sehingga mobilitasnya tidak terlalu berkurang banyak.

Pada tempat perdagangan retail dan rekreasi serta taman, mobilitas masyarakat ke dua tempat ini juga mengalami penurunan cukup drastis yaitu sekitar 40 persen. Hal ini selaras dengan peraturan 
pemerintah untuk menutup taman kota serta tempat lain yang dapat menimbulkan kerumunan. Untuk kebutuhan berbelanja, banyak masyarakat yang beralih ke e-commerce sebagai salah satu upaya untuk tetap melakukan aktivitas jual-beli tanpa melakukan kontak fisik. Penurunan sejak Bulan April terus terjadi hingga Bulan Mei. Pada bulan Juni mulai terjadi peningkatan mobilitas yang disebabkan oleh kebijakan New Normal. Kenaikan ini berlanjut hingga bulan Agustus yang kemudian mengalami penurunan lagi di Bulan September. Turunnya mobilitas masyarakat ke tempat-tempat umum seperti yang tertera pada Gambar 6 menunjukkan bahwa peraturan serta kebijakan yang dibuat oleh pemerintah terbukti dapat mengontrol mobilitas masyarakat. Hal ini sejalan dengan Pramana et al (2020) yang menunjukkan dengan berbagai sumber big data, terlihat bahwa pada masa adaptasi kebiasaan baru terdapat perbedaan pola kebiasaan masyarakat, seperti dalam hal mobilitas, kegiatan pariwisata, perubahan adopsi teknologi digital untuk berbelanja.

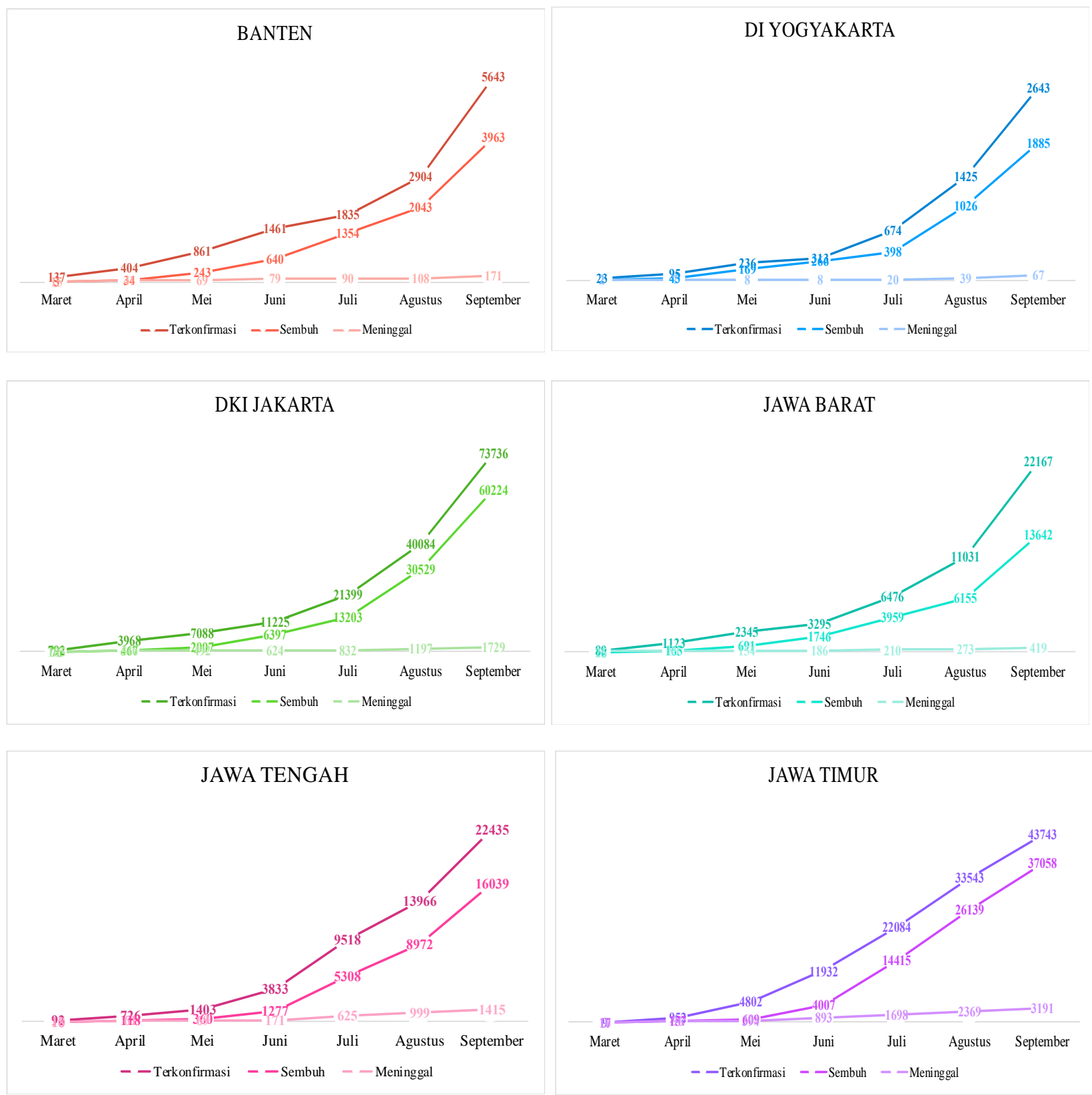

Gambar 7.

Jumlah Kasus Terkonfirmasi, Sembuh, dan Meninggal menurut Provinsi di

Pulau Jawa pada Bulan Maret-September 2020

Sumber: covid19.go.id (diolah) 


\section{Perkembangan Kasus Terkonfirmasi, Sembuh, dan Meninggal COVID-19 Berkaitan dengan Kebijakan Pemerintah menurut Provinsi di Pulau Jawa}

Berdasarkan hasil pengolahan data seperti yang tersaji pada Gambar 7 dapat dilihat bahwa keenam provinsi yang ada di Pulau Jawa memiliki pola yang sama untuk masing-masing kasus baik kasus terkonfirmasi, sembuh, maupun meninggal. Diantara provinsi lainnya, Banten dan DI Yogyakarta merupakan provinsi dengan kasus yang paling sedikit. Kedua provinsi ini memiliki kasus terkonfirmasi yang masih kurang dari sepuluh ribu sedangkan provinsi lainnya mencapai angka puluhan ribu. Hal ini membuat Kepala Daerah Provinsi DI Yogyakarta belum menerapkan kebijakan PSBB. Berbeda dengan DIY, Gubernur Banten menerapkan kebijakan PSBB selama satu bulan mulai 21 September hingga 20 Oktober 2020, hal ini mungkin dilakukan melihat pertambahan kasus yang terjadi dari bulan Agustus ke September mencapai lebih dari 2000 kasus padahal sejak Maret, pertambahan kasus perbulannya sekitar 1000 kasus.

Jika dibandingkan dengan Jawa Tengah dan Jawa Timur, kedua provinsi ini memiliki angka kepadatan penduduk yang lebih besar namun kasus terkonfirmasinya lebih sedikit. Hal ini menandakan bahwa kesadaran dari masyarakat di kedua provinsi ini lebih baik. Masyarakat lebih patuh terhadap regulasi-regulasi yang diberikan oleh pemerintah sehingga tingkat penyebaran virus COVID-19 lebih rendah dibanding provinsi lainnya. Untuk kasus meninggal, angka terbesar untuk DIY masih berada dibawah seratus dan untuk Banten angka terbesarnya adalah 171. Hal ini menandakan tingkat kematian yang ada di dua provinsi ini masih sangat kecil. Seiring dengan ini, tingkat kesembuhan yang ada di dua provinsi ini terbilang cukup baik yang menandakan bahwa fasilitas kesehatan yang ada cukup memadai.

Beralih ke DKI Jakarta, terlihat bahwa kasus terkonfirmasi pada Bulan September adalah 73.736 dimana angka ini sangat tinggi dibanding provinsi lain. Berkaitan dengan ini, sudah banyak kebijakan yang dikeluarkan oleh pemerintah namun faktanya, kebijakan-kebijakan ini belum bisa menurunkan angka positif COVID-19. Pada tanggal 13 Maret, Gubernur DKI Jakarta mengeluarkan surat edaran yang berisi tentang pemberlakuan kegiatan belajar di rumah, pembatasan penyelenggaraan acara, serta menutup sementara fasilitas taman dan hutan kota di Wilayah DKI Jakarta. Kemudian pada tanggal 16 Maret, pemerintah kembali mengeluarkan kebijakan Work. From Home (WFH). Hal ini dilakukan sebagai upaya untuk mencegah penyebaran virus COVID-19. Namun seperti yang terlihat pada Gambar 7 dari bulan Maret ke April, pertambahan kasus justru sangat banyak yaitu mencapai lebih dari 3000 kasus.

Pada 1 April, pemerintah menyelenggarakan rapid test dengan memprioritaskan warga berisiko tinggi dibantu Puskesmas. Hal ini menjadi penyebab bertambah banyaknya kasus positif karena jumlah orang yang diperiksa semakin banyak. Selanjutnya PSBB pertama kali dilakukan pada tanggal 10 April yang berlangsung selama dua minggu yang kemudian dilakukan perpanjangan hingga tanggal 22 Mei. Pertambahan kasus menjadi dua kali lipat pada Bulan Juni kemudian menjadi tiga kali lipat pada bulan Agustus. Hal ini mungkin terjadi karena banyak warga yang sudah jenuh dengan beraktivitas di rumah saja sehingga mereka mulai melakukan aktivitas keluar rumah yang menyebabkan pertambahan kasus sangat drastis. Selain itu pada 15 Mei bertepatan dengan Hari Raya Idul Fitri yang juga memungkinkan penyebaran virus menjadi semakin luas.

Pada tanggal 5 Juni, Gubernur DKI Jakarta menetapkan pemberlakuan PSBB Masa Transisi dimulai dengan pembukaan kembali transportasi umum dan juga sistem 50 persen karyawan dapat bekerja di kantor. Kemudian dilanjutkan dengan dibukanya kembali rumah ibadah. Hal ini mungkin menjadi penyebab peningkatan pada Bulan Agustus yang mencapai angka 40.000. Kemudian di awal Agustus, pemeriksaan virus COVID-19 di Jakarta 4 kali lipat lebih banyak dari standar WHO. Tingginya angka pada bulan Agustus ini menyebabkan pemerintah mengeluarkan kembali kebijakan PSBB namun sayangnya masyarakat sudah terbiasa untuk beraktivitas dengan kondisi PSBB transisi sehingga penyebaran virus COVID-19 belum bisa ditekan secara total.

Untuk kasus sembuh di DKI Jakarta, pertambahannya terus meningkat dari Maret hingga September. Hal ini terjadi karena sejak bulan April, pemerintah telah menyiapkan banyak rumah sakit serta puskesmas yang dijadikan rumah sakit rujukan COVID-19 sehingga penanganan terhadap kasus COVID-19 dapat dilakukan dengan maksimal. Hal ini juga membuat kasus meninggal di DKI Jakarta bukan yang tertinggi. Teknologi yang dimiliki oleh rumah sakit yang ada di Jakarta lebih canggih dibandingkan provinsi lainnya sehingga penanggulangan kasus COVID-19 dapat dilakukan dengan baik. 
Merujuk pada Gambar 7 terlihat bahwa meskipun kenaikan untuk kasus terkonfirmasi sangat tinggi, kenaikan untuk kasus sembuh juga sangat tinggi, apabila dibandingkan dengan provinsi lainnya.

Selanjutnya, untuk Provinsi Jawa Barat dan Jawa Tengah, jumlah kasus yang terkonfirmasi hampir sama setiap bulannya. Angka tertinggi untuk kedua provinsi ini adalah sekitar 22.000 kasus. Untuk kasus sembuh, Jawa Tengah memiliki angka yang lebih tinggi sekitar tiga ribu setiap bulannya, sementara untuk kasus meninggal, Jawa Tengah juga memiliki angka yang lebih tinggi dimana pada bulan September jumlah kasus meninggal mencapai 1.729 sedangkan Jawa Barat tidak mencapai angka seribu. Hal ini menunjukkan bahwa Jawa Tengah memiliki tingkat kesembuhan maupun tingkat kematian yang lebih tinggi daripada Jawa Timur. Ditinjau berdasarkan kebijakan yang berlaku, Jawa Tengah belum melakukan penerapan PSBB secara menyeluruh di tingkat Provinsi. Gubernur Provinsi Jawa Tengah mengambil langkah tegas berupa penegakan hokum jika masyarakat tidak disiplin terhadap protocol kesehatan COVID-19.

Di sisi lain, Pemerintah Provinsi Jawa Barat melakukan PSBB pada tanggal 15 April dan berlangsung selama dua minggu yang berlaku pada wilayah Bogor, Depok, dan Bekasi (Bodebek). Peningkatan yang terjadi di tiga wilayah ini kemungkinan cukup pesat akibat masih banyak warga yang keluar dan masuk dari DKI Jakarta. PSBB yang dilakukan berupa penghentian kegiatan belajar di sekolah, bekerja di kantor, rumah ibadah, serta pembatasan pengguna moda transportasi dengan kapasitas 50 persen. Karena kasus terkonfirmasi terus bertambah menjadi dua kali lipat pada bulan Agustus menuju September, maka Gubernur Jawa Barat kembali menerapkan PSBB wilayah Bodebek yang merupakan penyelarasan kebijakan pemerintah DKI Jakarta yang berlangsung hingga 11 Oktober 2020. Sementara untuk wilayah non-Bodebek diberlakukan kebijakan Adaptasi Kebiasaan Baru (AKB) dimana aktivitas diluar rumah dapat dilakukan seperti biasa dengan selalu mematuhi protokol kesehatan.

Untuk Provinsi Jawa Timur, kasus terkonfirmasi positif merupakan kedua tertinggi setelah DKI Jakarta. Hal ini mengkhawatirkan mengingat angka kepadatan penduduk Jawa Timur adalah yang terkecil dibandingkan provinsi lainnya. Pada bulan September, angka positif kasus COVID-19 mencapai 43.743. Lonjakan yang terjadi setiap bulannya cukup signifikan menyebabkan penerapan PSBB di Jawa Timur sudah dilakukan sejak Bulan April. Penerapan PSBB di Jawa Timur terjadi secara bertahap tidak langsung dalam skala provinsi. Tiga daerah pertama yang melakukan PSBB adalah Kota Surabaya, Kab. Sidoarjo, dan Kab. Gresik yaitu mulai tanggal 28 April. Hal ini dilakukan karena perkembangan kasus yang pesat terjadi di tiga daerah ini. Banyaknya kasus terkonfirmasi di Kota Surabaya juga mungkin disebabkan oleh laboratorium untuk pengujian COVID-19 yang hanya tersebar di kota sehingga pasien yang terpapar virus COVID-19 lebih mudah terdeteksi dibanding wilayah atau kabupaten lainnya.

PSBB selanjutnya diikuti oleh Kota Malang, Kabupaten Malang, dan Kota Batu yaitu pada tanggal 17 Mei. Hal ini dilakukan seiring banyaknya pertambahan kasus positif hingga bulan Mei yang sudah mencapai hampir 5.000 pasien. Selanjutnya kenaikan yang signifikan tetap terjadi hingga bulan September yang kemungkinan diakibatkan oleh pemberlakuan PSBB transisi dimana banyak warga yang sudah jenuh berada di rumah sehingga saat PSBB ditiadakan, mereka langsung melakukan aktivitas ke luar rumah seperti pergi ke pusat perbelanjaan ataupun fasilitas umum lainnya yang sebelumnya ditutup. Untuk kasus meninggal, Provinsi Jawa Timur merupakan provinsi dengan angka kematian yang paling tinggi. Sementara untuk kasus sembuh, angkanya juga cukup tinggi sama halnya dengan yang terjadi di DKI Jakarta.

Melihat perkembangan kasus COVID-19 di Pulau Jawa yang terus meningkat, membuat pemerintah yang ada di Pulau Jawa mendapat tantangan khusus untuk menanggulanginya. Meskipun memang sangat sulit untuk menahan penyebaran virus ini mengingat Pulau Jawa merupakan pulau dengan kepadatan penduduk tertinggi di Indonesia. Sudah banyak upaya yang dilakukan oleh pemerintah setempat untuk menekan penyebaran kasus COVID-19 namun pada kenyataannya angka nya terus bertambah. Hal ini terjadi karena alat test yang digunakan untuk mendeteksi virus semakin mudah ditemukan sehingga jumlah orang yang melakukan test juga semakin banyak. Selain itu juga diperlukan kesadaran dari individu masyarakat untuk menjaga dirinya dari virus COVID-19 dengan cara beraktivitas di rumah saja, ataupun hanya ke luar rumah jika sangat diperlukan, dengan tetap menerapkan protokol kesehatan. Meskipun jumlah kasus terkonfirmasi setiap bulannya mengalami kenaikkan, tetapi kasus sembuh juga turut mengalami kenaikkan. 


\section{Kesimpulan}

Jumlah pasien yang terkonfirmasi positif COVID-19 di Pulau Jawa terus mengalami peningkatan sejak Bulan Maret hingga September. Hal ini sejalan dengan bertambahnya pasien yang sembuh maupun pasien meninggal. Untuk kasus terkonfirmasi dan kasus sembuh, provinsi yang memiliki angka tertinggi adalah DKI Jakarta sementara untuk kasus meninggal, provinsi yang memiliki angka tertinggi adalah Jawa Timur. Upaya serta kebijakan yang diterapkan di tiap provinsi berbeda-beda karena kebijakan yang dibuat oleh pemerintah daerah terlebih dahulu diperiksa secara ketat dengan mempertimbangkan konsekuensinya sacara matang, baik dari segi ekonomi maupun sosial. Mobilitas masyarakat pada era pandemi mengalami penurunan terutama pada bulan April dan Mei. Mobilitas pada tempat kerja mengalami penurunan drastis saat kebijakan WFH ditetapkan. Mobilitas pada tempat-tempat umum juga mengalami penurunan seiring dengan peraturan pemerintah yang melarang kendaraan umum, taman kota, hingga tempat rekreasi untuk beroperasi. Peraturan yang dibuat pemerintah terlihat dapat merubah kebiasaan masyarakat terutama dalam hal mobilitas yang juga diharapkan dapat menekan penyebaran kasus COVID-19. Terlihat bahwa pertambahan kasus diiringi dengan semakin mudahnya akses untuk memeriksa COVID-19 sehingga lebih mudah untuk mendeteksinya. Selain itu mungkin saja apabila pemerintah tidak menerapkan berbagai kebijakan seperti PSBB, kasus yang ada di Indonesia sangat banyak melebihi jumlah saat ini. Pertambahan kasus positif juga sejalan dengan pertambahan kasus sembuh. Hal ini mengindikasikan bahwa penanganan pasien COVID-19 juga kian membaik setiap bulannya.

\section{Daftar Pustaka}

1. World Health Organization. Coronavirus [Internet]. 2020. Available from: https://www.who.int/healthtopics/coronavirus\#tab=tab_1

2. Koesmawardhani NW. Pemerintah Tetapkan Masa Darurat Bencana Corona hingga 29 Mei 2020. detiknews.com [Internet]. 2020; Available from: https://news.detik.com/berita/d-4942327/pemerintahtetapkan-masa-darurat-bencana-corona-hingga-29-mei-2020

3. Pramana Setia, Yuniarti, Paramatha Dede Yoga, Panununtun Satria Bagus. Mobility Pattern Changes In Indonesia In Response To COVID-19. 2021; Economics and Finance Indonesia Vol 67(1).

4. Sari HP. BNPB Rekomendasikan PSBB Diberlakukan di Seluruh Pulau Jawa. kompas.com [Internet]. 2020; Available from: https://nasional.kompas.com/read/2020/05/12/12193931/bnpb-rekomendasikanpsbb-diberlakukan-di-seluruh-pulau-jawa

5. Harapan Harapan, Naoya Itoh, Amanda Yufika, Wira Winardi, Synat Keam, Haypheng Te, Dewi Megawati , Zinatul Hayati , Abram L Wagner, Mudatsir Mudatsir. Coronavirus disease 2019 (COVID-19): A literature review. 2020; J Infect Public Health13(5):667-673. doi: 10.1016/j.jiph.2020.03.019

6. Aisyah DN, Mayadewi CA, Diva H, Kozlakidis Z, Siswanto, Adisasmito W. A spatial-temporal description of the SARS-CoV-2 infections in Indonesia during the first six months of outbreak. 2020; PLoS ONE 15(12): e0243703. https://doi.org/10.1371/journal.pone.0243703

7. Indonesia KKR. QnA : Pertanyaan dan Jawaban Terkait COVID-19 [Internet]. 2020. Available from: https://covid19.kemkes.go.id/qna-pertanyaan-dan-jawaban-terkait-covid-19/\#.X7TrEGUzbIU

8. Jayaweera M, Perera H, Gunawardana B, Manatunge J. Transmission of COVID-19 virus by droplets and aerosols: A critical review on the unresolved dichotomy. Environ Res. 2020; 188:109819. doi:10.1016/j.envres.2020.109819

9. Yunus NR, Rezki A, Nabi K, Saw M, Wabah M, Menular P. Kebijakan Pemberlakuan Lockdown Sebagai Antisipasi Penyebaran Corona Virus Covid-19. J Sos Budaya Syar-i. 2020;7(3):227-38.

10. Gitiyarko V. Upaya dan Kebijakan Pemerintah Indonesia Menangani Covid-19. kompas.id [Internet]. 2020 Jun; Available from: https://kompaspedia.kompas.id/baca/paparan-topik/upaya-dan-kebijakanpemerintah-indonesia-menangani-pandemi-COVID-19

11. Herdiana D, Nurul S. IMPLIKASI TATANAN NORMAL BARU TERHADAP KEHIDUPAN SOSIAL KEMASYARAKATAN. 2020;4(148):300-28.

12. Setiati S, Azwar MK. COVID-19 and Indonesia. 2020;52(1):84-9.

13. Djalante R, Lassa J, Setiamarga D, Mahfud C, Sudjatma A, Indrawan M, et al. Review and analysis of current responses to COVID-19 in Indonesia: Period of January to march 2020. J Pre-proof [Internet]. 2020;100091. Available from: https://doi.org/10.1016/j.pdisas.2020.100091

14. Badan Pusat Statistik. Survei Perilaku Masyarakat di Masa Pandemi Covid-19. 2020; Available from: https://www.bps.go.id/publication/2020/09/28/f376dc33cfcdeec4a514f09c/perilaku-masyarakat-dimasa-pandemi-covid-19.html 
15. Zulfaroh AN. Menyoal Tingginya Angka Kematian Covid-19 di Jatim... kompas.com [Internet]. 2020 Sep; Available from: https://www.kompas.com/tren/read/2020/09/11/080700865/menyoal-tingginyaangka-kematian-covid-19-di-jatim-?page=all 